Winter 2017

\title{
A Changed Taxonomy of Retail Financial Ratios
}

Thomas Zeller

Loyola University Chicago, tzeller@luc.edu

John W. Kostolansky

Loyola University Chicago, jkostol@luc.edu

Michail Bozoudis

Follow this and additional works at: https://ecommons.luc.edu/business_facpubs

Part of the Business Commons

\section{Recommended Citation}

Zeller, Thomas; Kostolansky, John W.; and Bozoudis, Michail. A Changed Taxonomy of Retail Financial Ratios. The Journal of Applied Business Research, 33, 6: 1069-1080, 2017. Retrieved from Loyola eCommons, School of Business: Faculty Publications and Other Works, http://dx.doi.org/10.19030/ jabr.v33i6.10046

This Article is brought to you for free and open access by the Faculty Publications and Other Works by Department at Loyola eCommons. It has been accepted for inclusion in School of Business: Faculty Publications and Other Works by an authorized administrator of Loyola eCommons. For more information, please contact ecommons@luc.edu.

\section{(c) (7)}

This work is licensed under a Creative Commons Attribution 4.0 International License.

(C) The Authors 2017 


\title{
A Changed Taxonomy Of Retail Financial Ratios
}

\author{
Thomas L. Zeller, Loyola University Chicago, USA \\ John Kostolansky, Loyola University Chicago, USA \\ Michail Bozoudis, Hellenic Air Force, Greece
}

\begin{abstract}
Thirty-five years ago researchers established a taxonomy of retail financial ratios. During the intervening period, extensive changes in retailing practices have been accompanied by equally extensive changes in financial reporting, marketing and management methods. Financial reporting standards have adapted to reflect these new domestic and international business practices, while technological innovation has produced continually evolving hardware and software advancements.

This study investigates the extent to which the taxonomy of retail financial ratios has changed and, if justified, will establish a revised taxonomy. It extends prior work in two ways. First, it utilizes advanced statistical methodologies and computing technologies to provide a more discriminating investigation than previous researchers were capable of conducting. Second, this study investigates the current taxonomy of retail industry financial ratios as well as its stability over a ten-year period.

Our findings identify a shift in the retail sector taxonomy of financial ratios. Empirical analysis points to a taxonomy consisting of five factors: capital intensiveness, cash position, inventory turnover, return on assets-return on sales, and return on equity-leverage. Contrary to expectations, a separate operating cash flow factor was not identified, despite the emergence of a mandatory cash flow statement during the intervening period. These findings provide an empirical basis to formulate testable hypotheses regarding the predictive and descriptive utility of retail financial ratios.
\end{abstract}

Keywords: Retail Sector Ratio Taxonomy; Retail Financial Statement Analysis; Factor Analysis; Retail Ratio Model Building

\section{INTRODUCTION}

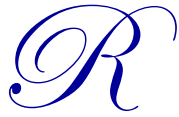

esearchers and analysts rely upon an empirically-based classification system, a taxonomy, to select appropriate ratios in the design of their financial studies. Reliance, however, is warranted only if the taxonomy exhibits a strong and stable structure (Altman and Eisenbeis, 1978). Barnes (1987) states that, "A model is only useful for predictive purposes if the underlying relationships and parameters are stable over time." The retail focused taxonomy of financial ratios in use today was last investigated 35 years ago. The purpose of this study is to identify the extent to which the taxonomy has changed, is stable, and if appropriate establish a new taxonomy.

This study extends prior work in two areas. First, we utilize advanced statistical methodologies and computing technologies that were unavailable to previous researchers, providing a more discriminating investigation than prior studies. Second, this study investigates not only the taxonomy of retail industry financial ratios, but also its stability over a ten-year period.

Much has changed in the retail business environment that calls into question the long-standing taxonomy of financial ratios. Financial reporting standards today are considerably different from those in existence when the taxonomy was first established. For example, a Statement of Cash Flows and a Statement of Comprehensive Income are now mandatory; neither was previously required. Other changes in accounting standards include the increased use of fair- 
market-value reporting in the balance sheet, goodwill impairment testing in lieu of amortization, and additional rules and disclosures relating to deferred taxes. These changes impact the values of many financial ratios and may also have altered the relationships among financial ratios.

To illustrate, cash flow reporting requirements (Financial Accounting Standard 95, The Statement of Cash Flows, enacted in November 1987) define and require the reporting of operating, investing and financing cash flows. Prior to 1987, financial statement users had to estimate a company's operating cash flows from the Statement of Sources and Uses of Funds, which varied greatly across companies and industries. Yet, operating cash flow is a component of many ratios that were studied prior to 1987. Several of these studies (discussed below) identified a separate cash flow factor in the retail ratio taxonomy. With a cash flow standard now in place, it is only logical to ask if the operating cash data used in ratio analysis today bears the same relationship to other ratios as the cash flow attribute used in the previous taxonomy research.

Technological improvements have changed the business practices of retailers. Advances in computing, both hardware and software, have turned inventory management into the science of timing the flow of merchandise, reducing inventory quantities to a minimum, and increasing inventory turnover. Electronic banking has undoubtedly affected cash management. For example, credit card purchases by customers result in near-immediate cash inflows. Firms are able to pay invoices on their due date while maintaining smaller cash balances and maximizing discount opportunities. Have these changes significantly affected the inventory turnover ratio, current ratio and other measures of liquidity as well their interrelationships? Researchers and financial analysts should logically ask if the retail sector taxonomy of financial ratios regarding cash position and liquidity are the same as that established 35 years ago.

This study investigates whether the long-standing taxonomy of financial ratios in the retail industry remains unchanged under today's financial reporting guidelines and current business practices. Specifically, the study identifies present day retail ratio factors and it ascertains if those factors are stable across this taxonomy. Our conclusions are limited to ratios derived from financial statements prepared in accordance U.S. generally accepted accounting principles (GAAP). The following sections review the literature, describe the research design, discuss the findings, and provide concluding comments.

\section{LITERATURE REVIEW}

Numerous studies attempted to identify the empirical relationships among various financial ratios. Using an analytical tool called factor analysis, Pinches and Mingo (1973); Pinches, Mingo and Caruthers (1973); Stevens (1973); Libby (1975); Pinches, Eubank, Mingo and Caruthers (1975) determined that financial ratios grouped into five to seven factors, across the manufacturing sector. The most comprehensive of these earlier studies (Pinches, Mingo, and Caruthers, 1973) concluded that financial ratio patterns for manufacturing firms correlate into seven factor groups and that the composition of the factor groupings was stable over the years studied.

Zeller, Kostolansky and Bozoudis (2016) identified a change to manufacturing firm factor groups compared to 35 years ago. Zeller et al. (2016) find that financial ratio patterns for manufacturing firms correlate into eleven factor groups and that the composition of the factor groupings was stable for the period 2004 to 2013. The manufacturing factor groupings changed in three notable areas. First, separate cash flow and liquidity factors did not surface. Second, the return on investment factor separated into three factors: return on asset, return on equity and return on sales. Third, a new factor surfaced in their work labeled current position, identified with two ratios -- current assets/total assets and current debt/total debt. Zeller et al. (2016) attribute the expansion of manufacturing factor patterns over previous studies to changes in reporting standards, business practices, and analytical tools not available in the period of previous studies. The changes identified in the manufacturing sector served as a basis to question the retail sector taxonomy of financial ratios in use today.

Johnson (1978) compared retail and manufacturing sector factor patterns. The study analyzed 61 ratios in a sample 159 retail firms using data from 1972 and identified nine similar manufacturing and retail factors. The nine factors demonstrated substantial cross-sectional stability, except for the "loose ends" factor, and explained 87 percent of the total variance for retail firms. The factors identified are: capital intensiveness, cash expenditure, cash position, 
decomposition measures, financial leverage, loose ends, inventory intensiveness, return on investments, receivable intensiveness, and short-term liquidity.

Johnson's (1978) findings confirmed the earlier works that focused primarily on manufacturing sector business activity. His study employed 40 of the ratios used in Pinches and Mingo (1973); Pinches, Mingo and Caruthers (1973); and Pinches, Eubank, Mingo and Caruthers (1975) studies and data from approximately the same years. The decomposition measures and loose ends factors are unique to Johnson's 1978 work.

Using data from 1972 and 1974 and the same 61 ratios, Johnson (1979) extended his previous study using the same retail firms. His second study identified eight manufacturing and retail factors, identical to his 1978 study. These factors demonstrated substantial cross-sectional stability in 1972 and 1974 and explained greater than 80 percent of the total variance for retail firms. A "loose ends" factor was not identified in the Johnson 1979 study.

Gombola and Ketz (1983) extend this research in a comprehensive study of 783 manufacturing firms and 88 retail firms over the period 1971 to 1980 . Only firms reporting a full set of requisite data from 1971 to 1980 were included. This work investigated the cross-industry stability of financial ratio patterns and the sensitivity of these patterns to differences in accounting constructs and used the 48 ratios in Pinches, Mingo, and Caruthers (1973), plus ten additional ratios to address "accounting constructs" such as "net income plus depreciation as a proxy for cash flow." Including the broader set of ratios resulted in identifying a 10-factor taxonomy of financial ratios for the retail industry. The ten factors are: capital intensiveness, cash expenditure, cash flow, cash position, financial leverage, turnover (labeled inventory intensiveness in related studies), return on investments, return on sales, receivable intensiveness, and shortterm liquidity. These factors remained stable over the period studied. The additional ratios included by Gombola and Ketz (1983) primarily loaded to the cash flow factor and the cash expenditure factor. We cannot explain why Gombola and Ketz (1983) identified a return on sales factor and Johnson $(1978,1978)$ did not, expect for a different time period of study and/or expanded financial ratio set.

Ketz, Dooger and Jensen (1990) investigated financial ratio taxonomies across seven industry sectors and one combined group called the economic sector, for the period 1978 to 1987 . This study analyzed 32 ratios "chosen on the basis of their popularity, usage in previous studies, and their usage in practice" and included a separate analysis of the retail business sector. Consistent with previous research, seven factors from the retail sector were identified, compared to the 10 factors from Gombola and Ketz (1983). We attribute the reduced number of factors to using a reduced number of ratios $(\mathrm{n}=32)$. Using fewer ratios is likely to result in fewer identified factors (Devine \& Seaton 1994/1995). Interestingly Ketz, Doogar, Jensen (1990). also identified a return on sales factor. The study did not explain why this factor was identified, when it was not in Johnson's $(1978,1979)$ work. The study by Ketz et al. (1990) is the latest factor analysis study focused on the retail industry financial ratios.

\section{RESEARCH DESIGN}

Data for this study were obtained from Compustat using SIC codes 5300 through 5900 (retail sector) for the years 2004 to 2013. This is the same window of time studied by Zeller et al. (2016) to enable comparability where appropriate. We included all firms reporting the requisite data for the chosen ratios for any year of the study. The studies by Gombola and Ketz (1983) and by Ketz et al. (1990) were limited to firms reporting the requisite data for all years of the study. However, Pinches et al. (1975) observed that limiting the sample of firms to only those firms reporting all data points for all years of inquiry may bias the sample toward profitable, leveraged firms. Devine and Seaton (1994/1995) provide evidence that restricting the sample of firms reduces the generalizability of research findings of the study. Thus, our study enhances the generalizability of its findings by not eliminating the impact of firms missing data for one (or more) years.

Table 1 lists the 58 ratios used in our study. These are the same ratios examined by Gombola and Ketz (1983) with two slight modifications. We replaced "current assets/total debt" (ratio no. 14) with "current liabilities/total debt." This allows for a relative comparison of the portion of debt that is current to other ratios. Gombola and Ketz (1983) found that the ratio of current assets/total debt did not load to any factor in any years of the study. Our second modification was to utilize the actual measure of cash flow from operations reported directly off a company's statement of cash flows. Previous studies estimated cash flow from operations by adjusting net income plus 
depreciation for accruals and deferrals because they preceded the introduction of a mandatory cash flow statement, highlighted in the introduction. Zeller et al. (2016) used the same 58 ratios to enable comparability where appropriate.

Table 1. Financial ratios

\begin{tabular}{|c|c|c|c|}
\hline No. & Ratio & No. & Ratio \\
\hline 1 & Cash/current debt & 30 & Total debt/total assets \\
\hline 2 & Cash/sales & 31 & Working capital/sales \\
\hline 3 & Cash/total assets & 32 & Working capital/total assets \\
\hline 4 & Cash/total debt & 33 & NIPD/equity \\
\hline 5 & Cash flow/equity & 34 & NIPD/sales \\
\hline 6 & Cash flow/sales & 35 & NIPD/total assets \\
\hline 7 & Cash flow/total assets & 36 & WCFO/equity \\
\hline 8 & Cash flow/total debts & 37 & WCFO/sales \\
\hline 9 & Cost of goods sold/inventory & 38 & $\mathrm{WCFO} /$ total assets \\
\hline 10 & Cost of goods sold/sales & 39 & NIPD/total capital \\
\hline 11 & Current assets/current debt & 40 & Income/total capital \\
\hline 12 & Current assets/sales & 41 & Current debt/net plant \\
\hline 13 & Current assets/total assets & 42 & Net worth/sales \\
\hline 14 & Current debts/total debt* & 43 & Sales/total assets \\
\hline 15 & EBIT/equity & 44 & Sales/net plant \\
\hline 16 & EBIT/sales & 45 & Sales/total capital \\
\hline 17 & EBIT/total assets & 46 & Sales/working capital \\
\hline 18 & Income/equity & 47 & Total debt/net plant \\
\hline 19 & Income/sales & 48 & Total debt/total capital \\
\hline 20 & Income/total assets & 49 & Total debt/net worth \\
\hline 21 & Inventory/current assets & 50 & Total assets/net worth \\
\hline 22 & Inventory/sales & 51 & Net income/total assets \\
\hline 23 & Inventory/working capital & 52 & Net income/net worth \\
\hline 24 & Long term debt/total assets & 53 & Net income/sales \\
\hline 25 & Quick assets/current debt & 54 & Current debt/net worth \\
\hline 26 & Quick assets/sales & 55 & Quick assets/fund expenditure (accrual) \\
\hline 27 & Quick assets/total assets & 56 & Cash/fund expenditure (accrual) \\
\hline 28 & Receivables/inventory & 57 & Quick assets/fund expenditure (cash) \\
\hline 29 & Receivables/sales & 58 & Cash/fund expenditure (cash) \\
\hline
\end{tabular}

*Revised from current assets/total debt

Principal Component Analysis (PCA), a method of factor analysis used in prior studies dating back to Pinches et al. (1973), was again used in the present study. For the same reasons as pointed out in Gombola and Ketz (1983), we did not perform log transformations on the data. "Factor analysis requires no distributional assumptions, allowing usage of non-normally distributed ratios. Also, because no decision model is specified, the variables are not required to take any particular distribution or forms."

To begin, we ran two tests to confirm the validity of conducting factor analysis on the retail ratio data sets. Previous studies did not conduct these tests. Table 2 shows the results. The Kaiser-Meyer-Olkin Measure of Sampling Adequacy (MSA) measures the proportion of variance in the dataset that may be caused by common underlying factors. Across all years, the MSA is greater than 63 percent, which is well above the 50 percent minimum for using factor analysis. The Bartlett's Test of Sphericity evaluates the hypothesis that the correlation matrix is an identity matrix. We find the p-values are less than 0.1 percent for each year, thus rejecting the null hypothesis of an identity matrix at the 5 percent significance level. Essentially, rejecting the null hypothesis suggests there is correlation among the ratios. 
Table 2. Descriptive and adequacy measures

\begin{tabular}{|c|c|c|c|}
\hline Year & Sample size & $\begin{array}{c}\text { Kaiser-Meyer-Olkin Measure } \\
\text { of Sampling Adequacy }\end{array}$ & $\begin{array}{c}\text { Bartlett's Test of } \\
\text { Sphericity } p \text {-value (required }<5 \% \text { ) }\end{array}$ \\
\hline 2004 & 228 & 0.726 & $<0.1 \%$ \\
\hline 2005 & 245 & 0.700 & $<0.1 \%$ \\
\hline 2006 & 244 & 0.698 & $<0.1 \%$ \\
\hline 2007 & 247 & 0.657 & $<0.1 \%$ \\
\hline 2008 & 255 & 0.704 & $<0.1 \%$ \\
\hline 2009 & 266 & 0.637 & $<0.1 \%$ \\
\hline 2010 & 273 & 0.652 & $<0.1 \%$ \\
\hline 2011 & 285 & 0.671 & $<0.1 \%$ \\
\hline 2012 & 305 & 0.693 & $<0.1 \%$ \\
\hline 2013 & 313 & 0.695 & $<0.1 \%$ \\
\hline
\end{tabular}

Identifying the respective factors requires several computational steps. We start with a separate correlation matrix of the 58 ratios for each year. We used a correlation matrix, rather than the variance-covariance matrix, to overcome the significant differences in magnitude across the ratio set. Next, the matrix is organized into independent groups, called factors. Factors represent a substantial amount of the information included in the original data set. The correlation coefficients between the original ratios and the identified factors are called factor loadings. The table of ratios and factor loadings is called a factor matrix. Next, the factor matrix was subjected to a varimax (orthogonal) rotation. This step maximizes the factor loading of each ratio on one factor, while at the same time minimizes the factor loading on all other factors. The subset of ratios with the highest correlation to the rotated independent factor matrix are used to identify the information signaled by the factor, therefore reducing the redundancy in the entire ratio set to that identified by the respective factors.

Selecting the number of factors is a blended process (Laurent, 1979; O'Connor, 2000; Gordon \& Courtney, 2013). The objective is to select stable factors that make a substantive contribution to explaining the variance in the ratio set and are interpretable. We defined a factor to be stable if the same ratios loaded to the factor in eight out of ten years. We appraised the PCA output against four extraction criteria to empirically set an upper and lower limit to the number of identifiable factors to be selected. This step is a substantial improvement over prior work. Studies discussed in the literature review used one criterion, Kaiser's eigenvalues-greater-than-one, as a methodology to selecting factors. As a result the previous published work may have over or underestimated the number of factors reported. Table 3 identifies the four extraction criteria, along with the respective advantages and disadvantages.

Table 3. Factor extraction criteria advantages and disadvantages

\begin{tabular}{|c|c|c|}
\hline Factor extraction criteria & Advantages & Disadvantages \\
\hline 1. Total Explained Variance & Flexible & Subjective \\
\hline $\begin{array}{l}\text { 2. Kaiser, also known as } \\
\text { eigenvalues great then } 1 \\
(\mathrm{~K} 1 \text { or } \mathrm{EV}>1)\end{array}$ & Objective, set to simple predefined limit & $\begin{array}{l}\text { Typically overestimates, and sometimes } \\
\text { underestimates the number of components } \\
\text { (Zwick \& Velicer, 1986). Components not } \\
\text { always reliable (Cliff, 1988). }\end{array}$ \\
\hline $\begin{array}{l}\text { 3. Velicer's Minimum } \\
\text { Average Partial (MAP) } \\
\text { test }\end{array}$ & $\begin{array}{l}\text { Statistically based. } \\
\text { According to O'Connor (2000), "focus is on } \\
\text { the relative amounts of systematic and } \\
\text { unsystematic variance remaining in a } \\
\text { correlation matrix." }\end{array}$ & Errs in under extraction \\
\hline $\begin{array}{l}\text { 4. Horn's Parallel Analysis } \\
\text { (PA) }\end{array}$ & $\begin{array}{l}\text { Statistically based. } \\
\text { According to O'Connor (2000), "focus is on } \\
\text { the number of components that account for } \\
\text { more variance than the components derived } \\
\text { from random data." }\end{array}$ & Errs in over extraction \\
\hline
\end{tabular}


Consistent with Pinches et al. (1973) and others, we required a factor loading between a respective ratio and the factor to be at an absolute value of .7 or greater in order to include the ratio as an interpretable factor loading. We disregarded factors, consistent with Gombola and Ketz (1983), when only one ratio had a factor loading with an absolute value at .7 or greater. Last, we evaluated the stability of a factor over time using a congruency coefficient defined by Harman (1976, p. 344) and used by Gombola and Ketz (1983).

\section{RESEARCH FINDINGS}

Table 4 identifies the average number of factors and the explained variance under different extraction criteria. The measures provide an objective overview across factor extraction methodologies, serving as a starting point for the next step of our analysis, which is to identify stable, interpretable factors across time.

Table 4. Average number of extracted factors and percent of explained variance

\begin{tabular}{l|c|c}
\hline \multicolumn{1}{c}{ Criterion } & \multicolumn{2}{c}{$\mathbf{2 0 0 4 - 2 0 1 3}$ Average } \\
\% of explained variance
\end{tabular}

We started the analysis by investigating factor models with $6,7,8,9$ and 10 factors extracted for each year. Factor loadings on the respective factors drove the analysis. We required two or more ratios with a factor loading having an absolute value of .7 or greater as a criteria for naming a factor. Consistent with prior research, two ratios were the minimum to interpret the type of factor measure. Also consistent with prior studies, we dropped factors where only one ratio had a factor loading with the absolute value of .7 or greater and extracted factors with all ratios loadings at less than .7 .

Over the periods 2004 to 2013, we identified 12 factors using the 8-factor model (See Table 5). We found that the 8factor taxonomy model provided the most meaningful insight. With the 6- and 7-factor models, a combination of ratios loaded in ways that confounded factor interpretability. With the 9 - and 10 -factor models, factors consisting of a single ratio emerged, thus reducing interpretability due to over-extraction. In addition, the incremental explained variance from the wider list of factors did not add clarity to the factor identification. For the 8-factor model, there was a balance between ratios loading to identifiable factors, with substantial explained variance, yet an occasional single ratio loading to a single factor in the respective factor matrix with an explained variance greater than .7 . 
Table 5. 8-Factor model 2004 to 2013

\begin{tabular}{|c|c|c|c|c|c|c|c|c|c|c|}
\hline \multirow[b]{2}{*}{ Factor identity } & \multicolumn{10}{|c|}{ Year } \\
\hline & 2004 & 2005 & 2006 & 2007 & 2008 & 2009 & 2010 & 2011 & 2012 & 2013 \\
\hline 1) Capital intensiveness (debt ratio) & $\mathrm{X}$ & $\mathrm{X}$ & $\mathrm{X}$ & $\mathrm{X}$ & $\mathrm{X}$ & $\mathrm{X}$ & $\mathrm{X}$ & $\mathrm{X}$ & $\mathrm{X}$ & $\mathrm{X}$ \\
\hline 2) Cash position & $X$ & $\mathrm{X}$ & $\mathrm{X}$ & $\mathrm{X}$ & $\mathrm{X}$ & $\mathrm{X}$ & $\mathrm{X}$ & $\mathrm{X}$ & $\mathrm{X}$ & $\mathrm{X}$ \\
\hline 3) Financial leverage & & & & $\mathrm{X}$ & & & $\mathrm{X}$ & & $\mathrm{X}$ & $\mathrm{X}$ \\
\hline 4) Financial leverage/ return on equity & & & & $\mathrm{X}$ & & & & $\mathrm{X}$ & & \\
\hline 5) Fund expenditure (cash and accrual) & & & & & $\mathrm{X}$ & & $\mathrm{X}$ & & & \\
\hline 6) Inventory turnover & $\mathrm{X}$ & $\mathrm{X}$ & $\mathrm{X}$ & $\mathrm{X}$ & $\mathrm{X}$ & $\mathrm{X}$ & $\mathrm{X}$ & $\mathrm{X}$ & $\mathrm{X}$ & $\mathrm{X}$ \\
\hline 7) Liquidity & $\mathrm{X}$ & $\mathrm{X}$ & $\mathrm{X}$ & & & $\mathrm{X}$ & & & & $\mathrm{X}$ \\
\hline 8) Return on assets-return on sales & $\mathrm{X}$ & $\mathrm{X}$ & $\mathrm{X}$ & $\mathrm{X}$ & $\mathrm{X}$ & $\mathrm{X}$ & $\mathrm{X}$ & $\mathrm{X}$ & $\mathrm{X}$ & $\mathrm{X}$ \\
\hline 9) Return on capital & & & $\mathrm{X}$ & & $\mathrm{X}$ & & & & & \\
\hline 10)Return on equity-leverage & $\mathrm{X}$ & $\mathrm{X}$ & $\mathrm{X}$ & $\mathrm{X}$ & $\mathrm{X}$ & $\mathrm{X}$ & $\mathrm{X}$ & $\mathrm{X}$ & $\mathrm{X}$ & $\mathrm{X}$ \\
\hline 11)Return on sales & & $\mathrm{X}$ & & & & $\mathrm{X}$ & & & & \\
\hline 12)Working capital & $\mathrm{X}$ & $\mathrm{X}$ & & & & & & & & \\
\hline Total extracted factors & 8 & 8 & 8 & 8 & 8 & 8 & 8 & 8 & 8 & 8 \\
\hline Total explained variance & $80 \%$ & $81 \%$ & $77 \%$ & $76 \%$ & $78 \%$ & $72 \%$ & $74 \%$ & $73 \%$ & $74 \%$ & $73 \%$ \\
\hline
\end{tabular}

Five (highlighted in gray) of the 12 factors were interpretable and stable over the entire period, 2004 to 2013: capital intensiveness (debt ratio), cash position, inventory turnover, return on assets-return on sales, and return on equityleverage. The remaining factors were not stable. Although a liquidity factor was identified in the early years, it emerged only once after 2009. For the period 2004 to 2013, the average explained variance with 8 factors is 76 percent, ranging between 72 to 81 percent.

Table 6 lists the stable factors, factors that were identifiable in all years of the study, and their congruency coefficient. The interpretation of a congruency coefficient is analogous to a correlation coefficient. The mean absolute congruency coefficient for the stable factors falls in the ranges of .62 to .89 providing evidence that the five factors are stable for the period 2004 to 2013.

Table 6. Mean Absolute Congruency Coefficient for Stable Factors

\begin{tabular}{l|c}
\hline \multicolumn{1}{c}{ Factor } & Mean Absolute Congruency Coefficient for Stable Factors \\
\hline Capital intensiveness (debt ratio) & .65 \\
\hline Cash position & .88 \\
\hline Inventory turnover & .62 \\
\hline Return on assets -return on sales & .89 \\
\hline Return on equity - leverage & .78 \\
\hline
\end{tabular}

Tables 5, 6 and 7 guide our discussion of the individual factors and ratios that consistently load to the five stable retail factors. To begin, the findings confirm the capital intensiveness factor. The capital intensiveness factor loaded in each year for the period 2004 to 2013. Johnson $(1978,1979)$ and Gombola and Ketz (1983) identified the capital intensiveness factor with the same ratios listed on Table 7. The Ketz et al. (1990) ratio set of 32 ratios did not include capital intensiveness measures, and thus a capital intensive factor was not identified. Zeller et al. (2016) identified a stable capital intensiveness factor for the manufacturing sector, with the same ratios, yet a higher congruency coefficient. 
Table 7. Ratios loading to respective factors

\begin{tabular}{|c|c|c|c|}
\hline Capital intensiveness (debt ratio) & & Return on assets-return on sales & \\
\hline Current debt/ net plant & 9 of 10 years & Cash flow/ sales & 8 of 10 years \\
\hline Total debt/ net plant & 8 of 10 & Cash flow/ total assets & 10 of 10 \\
\hline Cash position & & EBIT/ sales & 8 of 10 \\
\hline Cash/ current debt & 10 of 10 & EBIT/ total assets & 10 of 10 \\
\hline Cash/ total assets & 8 of 10 & Income/ sales & 10 of 10 \\
\hline Cash/ total debt & 10 of 10 & Income/ total assets & 10 of 10 \\
\hline Inventory turnover & & Net income/ sales & 9 of 10 \\
\hline Cost of goods sold/ inventory & 7 of 10 & Net income/ total assets & 10 of 10 \\
\hline Inventory/ current assets & 7 of 10 & NIPD/ sales & 9 of 10 \\
\hline \multirow[t]{10}{*}{ Inventory/sales } & 9 of 10 & NIPD/ total assets & 10 of 10 \\
\hline & & $\mathrm{WCFO} /$ total assets & 8 of 10 \\
\hline & & Return on equity- leverage & \\
\hline & & Cash flow/ equity & 9 of 10 \\
\hline & & Current debt/ net worth & 9 of 10 \\
\hline & & EBIT/ equity & 8 of 10 \\
\hline & & NIPD/ equity & 7 of 10 \\
\hline & & Total assets/ net worth & 10 of 10 \\
\hline & & Total debt/ net worth & 10 of 10 \\
\hline & & WCFO/ equity & 10 of 10 \\
\hline
\end{tabular}

Although capital intensiveness is a stable factor, its congruency coefficient is comparatively low at .65. Gombola and Ketz (1983) (p. 54) report an average capital intensiveness congruency coefficient of .91. The low congruency coefficient suggests capital intensiveness in the retail sector may be in a period of transition. Further research is necessary to clarify why we are finding a stable, yet a lower congruency coefficient than previous research.

Tables 5, 6 and 7 point to a very stable cash position factor. Note that this factor loads every year for the period 2004 to 2013 and its congruency coefficient stands at .88. Johnson (1978, 1979), Gombola and Ketz (1983) and Ketz et al. (1990) identified a stable cash position factor with the same ratios listed in Table 7. We interpret this finding as evidence to suggest cash and cash equivalent amounts in respect to current debt, total assets and total debt represent a distinct perspective in financial ratio analysis. Zeller et al. (2016) identified a stable cash position factor for the manufacturing sector, with similar ratios, as well as a high congruency coefficient.

Identifying a stable cash position factor but not a stable liquidity factor deserves further discussion. Zeller et al. (2016) did not identify a stable liquidity factor for the manufacturing sector. The findings suggest that liquidity may no longer be a unique analytical factor for the retail sector or the manufacturing sector. The liquidity factor loaded in only 5 of the 10 years and in only one year of the most recent 5 years. Why? Current inventory management tools and techniques across the retail sector may offer some insight. Does technology enable retailers to operate with less working capital, thereby moving the current ratio closer to 1 and invalidating the current ratio as a traditional measure of liquidity? Given the stability of the cash position factor and lack of stability in the liquidity factor, it would appear that cash position would be a better estimate of a retail firm's ability to pay, i.e. liquidity.

Table 5 shows the financial leverage factor was unstable, identified in only 4 of the 10 years. Yet, Johnson (1978, 1979) and Gombola and Ketz (1983) identified a stable financial leverage factor. Ratios loading to the financial leverage factor in previous research were weakly correlated (less than .7) and/or inconsistent, occasionally loading to the capital intensiveness factor in our study. Exploring the retail sector's use of financial leverage may provide additional insight. Perhaps management is rethinking the optimal level of debt? Perhaps changes in composition of on-line sales relative to brick-and-mortar sales are impacting these ratios. Changes in financial reporting standards such as those for lease accounting may also be impacting management's choices. These questions bear further inquiry into the shifting landscape around retail capital intensiveness. Zeller et al. (2016) identified a stable financial leverage factor for the manufacturing sector. This finding would suggest the retail environment application of financial leverage is less stable than the manufacturing environment, deserving future research to identify why. 
Our findings confirm the inventory turnover factor. The factor loaded in each year for the period 2004 to 2013. Johnson (1978, 1979), Gombola and Ketz, (1983) and Ketz et al. (1990) identified the inventory turnover factor with the same ratios listed in Table 7. Zeller et al. (2016) identified a stable inventory turnover factor for the manufacturing sector, with similar ratios, and a high congruency coefficient.

Although stable, the inventory turnover factor congruency coefficient is low at .62. Gombola and Ketz (1983, p. 54) reported an average inventory turnover congruency coefficient of .96. Further research is necessary to clarify why we found a stable, yet comparatively lower congruency than previous research. Does the limited stability signal changes underway in inventory management across the retail sector? Have changes to financial reporting rules clouded the clarity previously identified in the area of inventory turnover? Both are questions deserving further study.

Tables 5, 6 and 7 also suggest that the return on assets-return on sales factor is very stable. The factor loaded each year for the period 2004 to 2013. The congruency coefficient stands at .89. This result is consistent with prior research studies. Gombola and Ketz (1983) and Ketz et al. (1990) identified a stable return on assets-return on sales factor comprised of the same ratios. This finding suggests return on assets and return on sales are highly correlated in the retail sector. Zeller et al. (2016) identified separate return on asset and return on sales factors for the manufacturing sector. We suspect the difference in operating environment is driving the difference in factor loading between the retail and manufacturing sectors.

Tables 5, 6 and 7 likewise substantiate that the return on equity-leverage factor is very stable. This factor loaded every year for the period 2004 to 2013 and its congruency coefficient stands at .78. Prior work did not identify a distinct return on equity-leverage factor. Table 7 shows the consistency in the ratios that load to this factor. The findings provide evidence that return on equity and leverage ratios are correlated. Zeller et al. (2016) did not identify a return on equity and leverage factor.

Absent in this study is the identification of a stable cash flow factor. Gombola and Ketz (1983) and Ketz et al. (1990) reported a stable cash flow factor. However, none of the factor models evaluated in this study evidenced a cash flow factor, regardless the number of factors under investigation. We found cash flow ratios consistently loaded to the return on assets-return on sales factors. Zeller et al. (2016) did not find a separate cash flow factor. The findings call into questions the usefulness of operating cash flow as a unique performance measure in the retail and manufacturing sectors. However, our findings confirmed the use of operating cash flows as a quality of earnings measure, where quality is defined as an approximation of accrual based earnings. The findings showed that cash flow ratios are correlated with traditional performance measures with respect to sales and total assets.

\section{SUMMARY AND CONCLUSION}

This study was conducted to determine if the taxonomies identified by earlier studies for the retail sector have been changed as a result of changes in business practices, economic conditions, and financial reporting requirements. Researchers and financial analysts can and should logically ask if today's taxonomy of financial ratios is still the same as that established 35 years ago.

We empirically investigated this issue using enhanced research tools and techniques that were unavailable to the previous researchers. We applied tests to evaluate the validity of conducting factor analysis on the financial ratio data sets and we tested four different factor extraction criteria. This work guides the range of factors to explore and evaluate for interpretability and stability. Prior work used the simple Kaiser criterion which extracts those factors with eigenvalues greater than 1 as the cutoff for the factor extraction. Last, we did not limit our sample to include only those firms reporting all the requisite data for all years of the study. This step, along with not performing a $\log$ transformation on the ratios, enables a wider generalizability of our findings.

The 8-factor model suggests a shift in the retail sector financial ratio taxonomy for firms preparing financial statements in conformity with U.S. generally accepted financial reporting standards. The findings point to five stable factors: capital intensiveness, cash position, inventory turnover, return on assets-return on sales and return on equity-leverage. The findings also point to a lack of a separate liquidity and a separate cash flow factor. The lack of separate liquidity and cash flow factors is consistent with Zeller et al. (2016). An explanation of why these factors did not surface is left 
for future research. At best we speculate that changes to business practices and financial reporting standards are influencing the ratio measures, correlations, and thus factor loadings. An interesting question for future research will be to determine if a similar taxonomy holds for ratios derived from financial statements prepared under international financial reporting standards.

\section{AUTHOR BIOGRAPHIES}

Thomas L. Zeller: Professor, Department of Accounting and Business Law in the Quinlan School of Business at Loyola University Chicago. He has published numerous articles and books. His research appears in a wide variety of academic and practitioner journals, such as, Strategic Finance, Journal of Accounting and Public Policy, Journal of Applied Business Research, Business Horizons, Healthcare Financial Management, and Issues in Accounting Education. Current research interest are in financial ratio analysis and case development. He teaches graduate and undergraduate level courses. He is a member of the American Accounting Association, Illinois CPA Society and, American Institute of Certified Public Accountants. E-mail: tzeller@luc.edu

John Kostolansky: Associate Professor, Department of Accounting and Business Law in the Quinlan School of Business at Loyola University Chicago. He has published teaching cases and articles on the impact of new accounting standards, the link between firm size and choice of accounting standards and the changing information content of accounting ratios over time. His research has been published in journals such as the Journal of Economic Asymmetries, Issues in Accounting Education, Journal of Applied Business Research, and the Journal of Business Case Studies. He teaches graduate classes in financial accounting, international accounting, and financial analysis in School's MBA and Health Care MBA Program. He is a member of the American Accounting Association and a Certified Public Accountant. E-mail: jkostol@luc.edu

Michail Bozoudis: Senior Officer, Hellenic Ministry of National Defense, responsible for data analysis, forecasting, and military programs life cycle costing. He holds several academic and professional qualifications including an Engineering Degree, Master of Science in Applied Statistics, and a Master in Business Administration. His research appears in a variety of academic and practitioner publications, such as, the American Journal of Business, the Journal of Reliability, Maintainability, and Supportability in Systems Engineering, and Wolfram Mathematica. Current Research interests are in financial ratio analysis and American option pricing models. He teaches Cost and Quantitative Analysis in the Air Force Technical NCO Academy, Greece. He is a member of NATO System Life Cycle Management Group AC/327. E-mail: mbozmboz@yahoo.com

\section{REFERENCES}

Altman, E. I., \& Eisenbeis, R. A. (1978). Financial applications of discriminant analysis: a clarification. Journal of Financial and Quantitative Analysis, 185-195.

Barnes, P. (1987). The Analysis and use of finanical ratios: a review article. Journal of Business Finance \& Accounting, 14(4), 449-461.

Cliff, N. (1988). The Eigenvalues-greater-than-one rule and the reliability of components. Psychological Bulletin, 48, 687-692.

Devine, K., \& Seaton, L. (1994/1995). A Examination of quarterly financial ratio stability: implictions for financial deciion making. Journal of Applied Business Research, 11(1), 81-97.

Gombola, M. J., \& Ketz, J. E. (1983). Financial Ratio patterns in retail and manufacturing organizations. Financial Management (12), 45-56.

Gordon, M., \& Courtney, R. (2013). Determining the number of factors to retain in EFA: Using the SPSS R-menu v2.0 to make more juidicious estimations. Practical Assessment Research \& Evaluation, 18(8), pp. 1-14.

Harman, H. H. (1976). Modern Factor Analysis. University of Chicago Press.

Johnson, W. B. (1978). The Cross-sectional stability of financial patterns. Journal of Business Finance \& Accounting, $5(2), 207$ 213.

Johnson, W. B. (1979). The Cross-sectional stability of financial ratio patterns. Journal of Financial and Quantitative Analysis, $X I V(5), 1035-1048$.

Ketz, J. E., Doogar, R. K., \& Jensen, D. E. (1990). A Cross-Industry Analysis of Financial Ratios. New York: Quorum Books.

Laurent, C. R. (1979). Improving the Efficiency and effectiveness of financial ratio analysis. Journal of Business Finance \& Accounting, 6(3), 401.

Libby, R. (1975, Spring). Accounting Ratios and the prediction of failure: some behavioral evidence. Journal of Accounting Research, 150-161. 
O'Connor, B. P. (2000). SPSS and SAS programs for determing the number of components using parallel analysis and Velicer's MAP test. Behaviour reserach Methods, Instruments, \& Computers, 32, pp. $396-402$.

Pinches, G. E., \& Mingo, K. A. (1973, March). A Multivariate analysis of industrial bond ratings. Journal of Finance, 1-18.

Pinches, G. E., Eubank, A. A., Mingo, K. A., \& Caruthers, J. K. (1975, October). The hierarchical classification of financial ratios. Journal of Business Research, 3(4), 295-309.

Pinches, G. E., Mingo, K. A., \& Caruther, J. K. (1973). The stability of financial patterns in industrial organizations. The Journal of Finance, 28(2), 389-396.

Stevens, D. L. (1973, March). Financial characteristics of merged firms: a multivariate analysis. Journal of Financial and Quantitative Analysts, 149-158.

Zeller, T., Kostolansky, J., \& Bozoudis, M. (2016). Have changes in business practices and reporting standards changed the taxonomy of financial ratios? American Journal of Business, 31(2), 85-97.

Zwick, W. R., \& Velicer, W. F. (1986). Comparisons of five rules for determining the number of componets to retain. Psychological Fulletin, 99, 432-442. 


\section{NOTES}

